\title{
FAKTOR PENDUKUNG DAN PERAN BRIGADE PENGENDALIAN KEBAKARAN HUTAN PADA BALAI TAMAN NASIONAL WAY KAMBAS
}

\section{SUPLEMENTARY FAKTOR AND ROLE OF BRIGADE OPERATION FOREST FIRE AT WAY KAMBAS NATIONAL PARK}

\author{
Oleh/by: \\ Sukarman \\ Balai Taman Nasional Way Kambas \\ J1. Labuhan Ratu Lama, Labuhan Ratu Sukadana, Lampung Timur \\ e_mail Karman_btnwk@yahoo.co.id, Hp. 081272035005
}

\begin{abstract}
ABSTRAK
Kawasan Taman Nasional Way Kambas (TNWK) mengalami kerusakan habitat selama 20 tahun terakhir, diantaranya disebabkan kebakaran hutan yang diduga dipicu tidak hanya faktor alam namun juga akibat ulah manusia sehingga peran serta petugas pengendalian kebakaran hutan sangat diperlukan untuk menjaga dan memelihara hutan. Penelitian ini bertujuan untuk mempelajari faktor pendukung dan peran brigade pengendalian kebakaran hutan (brigdalkarhut) di TNWK. Metode pengambilan data menggunakan metode sensus dan survei. Populasi hanya berjumlah 41 orang sehingga semuanya diambil sebagai sampel. Data dianalisis dengan uji korelasi. Berdasarkan hasil penelitian diketahui bahwa peran serta dalam pengendalian kebakaran hutan rata-rata bernilai sedang. Hasil uji korelasi Rank Spearman's Rho menyatakan bahwa tidak ada hubungan yang signifikan antara faktor pelengkap dan peran brigade kebakaran hutan.
\end{abstract}

Kata kunci : Peran, Brigdalkarhut

\begin{abstract}
During the last 20 years, Way Kambas National Park's area has experienced of the habitat damage, is among other things caused by a forest fire and to be triggered do not only natural faktor but also effect of is act human being. Role and also worker very needed to take care of and look after Way Kambas National Forest. Objective of this research is to learn the relation between supplementary faktors and roles of brigade of forest fire to forest fire prevention at Way Kambas National Park. Population as well as samples were 41 peoples. Data was analyzed by rank Spearman correlation. Result of research showed that the role and also in contribution of activity of forest fire control was at moderate category and no significance result on correlation between supplementary faktors and roles of brigade of forest fire.
\end{abstract}

Key Word: role, forest fire, national park, brigade.

\section{PENDAHULUAN}

Hutan merupakan suatu pondasi alam dalam menyediakan dan mengendalikan berbagai kebutuhan manusia, seperti udara, air dan sebagainya. Selain sebagai sumber daya alam hutan juga merupakan faktor ekonomi dilihat dari hasil-hasil yang dimilikinya. (Adinugroho WCI, Saharjo SBH dan Siboro L, 2004). 
Seiring dengan berjalannya waktu, terutama setelah ditetapkannya sebagai kawasan suaka margasatwa, TNWK banyak terjadi gangguan hutan. Kawasan bahkan mengalami kerusakan habitat yang cukup berat selama 20 tahun terakhir akibat kebakaran. Kebakaran tersebut diduga dipicu tidak hanya faktor alam misalnya udara yang sangat panas disaat musim kemarau namun juga akibat ulah manusia yang tidak sadar akan pentingnya hutan dan sikap yang ceroboh misalnya membuang puntung rokok sembarangan atau lupa memadamkan api ketika berada di kawasan hutan serta kegiatan produktif yang dilakukan masyarakat sekitar TNWK. Mengingat penyebab kebakaran dipicu oleh aktivitas masyarakat di dalam dan sekitar kawasan, kegiatan pencegahan harus ditingkatkan dengan lebih memperhatikan akar permasalahan penyebab kebakaran yaitu faktor sosial ekonomi masyarakat (Khulfi dkk, 2015). Lebih lanjut Suheri dan Purnomo (2017), menyatakan kebakaran hutan dan lahan disebabkan dua faktor utama yaitu kebakaran didukung oleh pemanasan global/kemarau ekstrim yang sering dikaitkan dengan pengaruh iklim dan aktivitas manusia dalam pengelolaan hutan. Persentase dari kegiatan manusia sebanyak $99 \%$ baik disengaja maupun unsur kelalaian.

Memahami kondisi tersebut faktor pendukung dan peran petugas pemadam kebakaran hutan sangat diperlukan untuk menjaga dan memelihara hutan. Upaya pemerintah yang dilakukan untuk meminimalisir kebakaran belum banyak menyentuh upaya kegiatan pencegahan (Anih dan Suryani, 2012). Selanjutnya dengan Surat Keputusan Kepala Balai Taman Nasional No 11/BTN-WK tahun 2017 dibentuk personil Brigdalkarhut, yaitu satuan kerja yang mempunyai tugas dan tanggung jawab untuk melaksanakan kegiatan pencegahan, pemadaman, penanganan pasca kebakaran serta dukungan evakuasi dan penyelamatan dalam pengendalian kebakaran hutan dan lahan di lapangan (Permen LHK RI No:P.32/Menlhk/Setjen/Kum.1/3/2016 tentang Pengendalian kebakaran hutan). Pengendalian kebakaran hutan meliputi usaha/kegiatan/tindakan pengorganisasian, pengolahan sumber daya manusia dan sarana prasarana serta operasional pencegahan, pemadaman, penanganan pasca kebakaran, dukungan evakuasi dan penyelamatan serta dukungan manajemen pengendalian kebakaran hutan.

Tujuan penelitian ini adalah mempelajari faktor pendukung dan peran anggota Brigdalkarhut pada pengendalian kebakaran hutan di wilayah Taman Nasional Way Kambas.

\section{METODOLOGI PENELITIAN}

Penelitian dilakukan dari bulan November 2015 sampai dengan Januari 2016 pada Unit Pelaksana Teknis (UPT) Balai Taman Nasional (BTN) Way Kambas. Populasi sekaligus sampel dalam penelitian yaitu anggota Brigdalkarhut di Balai Taman Nasional Way Kambas. Semua anggota diambil sebagai responden, karena jumlahnya kurang dari 100 (41 orang) Sugiyono (2009). Data yang digunakan dalam penelitian ini ada 2 (dua) macam, yaitu data primer yang diperoleh langsung dari sumber penelitian yang didapatkan melalui wawancara, observasi atau kuesioner dan data sekunder. Penghimpunan skor dilakukan dengan menggunakan skala Likert yang terdiri dari pertanyaan dengan jawaban dengan sering (diberi skor 3), pernah (diberi skor 2) dan tidak pernah (diberi skor 1) dan pernyataan tidak setuju (diberi skor 1), setuju (diberi skor 2) dan sangat setuju (diberi skor 3) (Nasution, 2012) Penentuan kategori digunakan interval kelas (Yitnosumarto, 1994). Pengolahan dan analisis data dilaksanakan dengan menggunakan metode tabulasi, sedangkan pengujian hipotesis menggunakan Statistik Non parametrik Korelasi Rank Spearman Rho dalam aplikasi SPSS 17 (Stastistical Package for the Social Science) (Dwi, 2008). Untuk mengetahui signifikansi antara variabel faktor pendukung dengan peran brigdalkarhut dalam pengendalian kebakaran 
hutan digunakan uji t (Siegel, 1986). Variabel yang diuji yaitu faktor pendukung peran brigdalkarhut meliputi: $\mathrm{X} 1=$ pengalaman responden pada sumber-sumber api yang dapat menimbulkan kebakaran hutan, X2= keterangan dan sumber-sumber api yang diketahui responden sebagai sebab timbulnya kebakaran, $\mathrm{X} 3=$ Mendapatkan sumber inovasi dan pengetahuan yang dimiliki responden pada pengendalian kebakaran dan $\mathrm{X} 4=$ bentuk program kerja dalam menunjang keberhasilan pengendalian kebakaran hutan) terhadap peran anggota Brigdalkarhut meliputi: (Y1=peran perencanaan kegiatan pengendalian kebakaran hutan, Y2=peran pelaksanaan kegiatan pengendalian kebakaran hutan, Y3=peran organisasi kerja dan pemeliharaan pengendalian kebakaran hutan dan $\mathrm{Y} 4=$ peran pencapai tujuan dan penilaian pengendalian kebakaran hutan) di TNWK.

\section{HASIL DAN PEMBAHASAN}

\section{Faktor Pendukung Peran Brigdalkarhut Pada Pengendalian Kebakaran}

Faktor pendukung adalah hal atau kondisi yang dapat mendorong atau menumbuhkan kegiatan organisasi, lembaga atau unit produksi Kamus Besar Bahasa Indonesia (KBBI), (2017). Faktor pendukung peran brigdalkarhut hasil penelitian dapat dilihat pada Tabel 1.

Tabel 1. Faktor pendukung peran brigdalkarhut

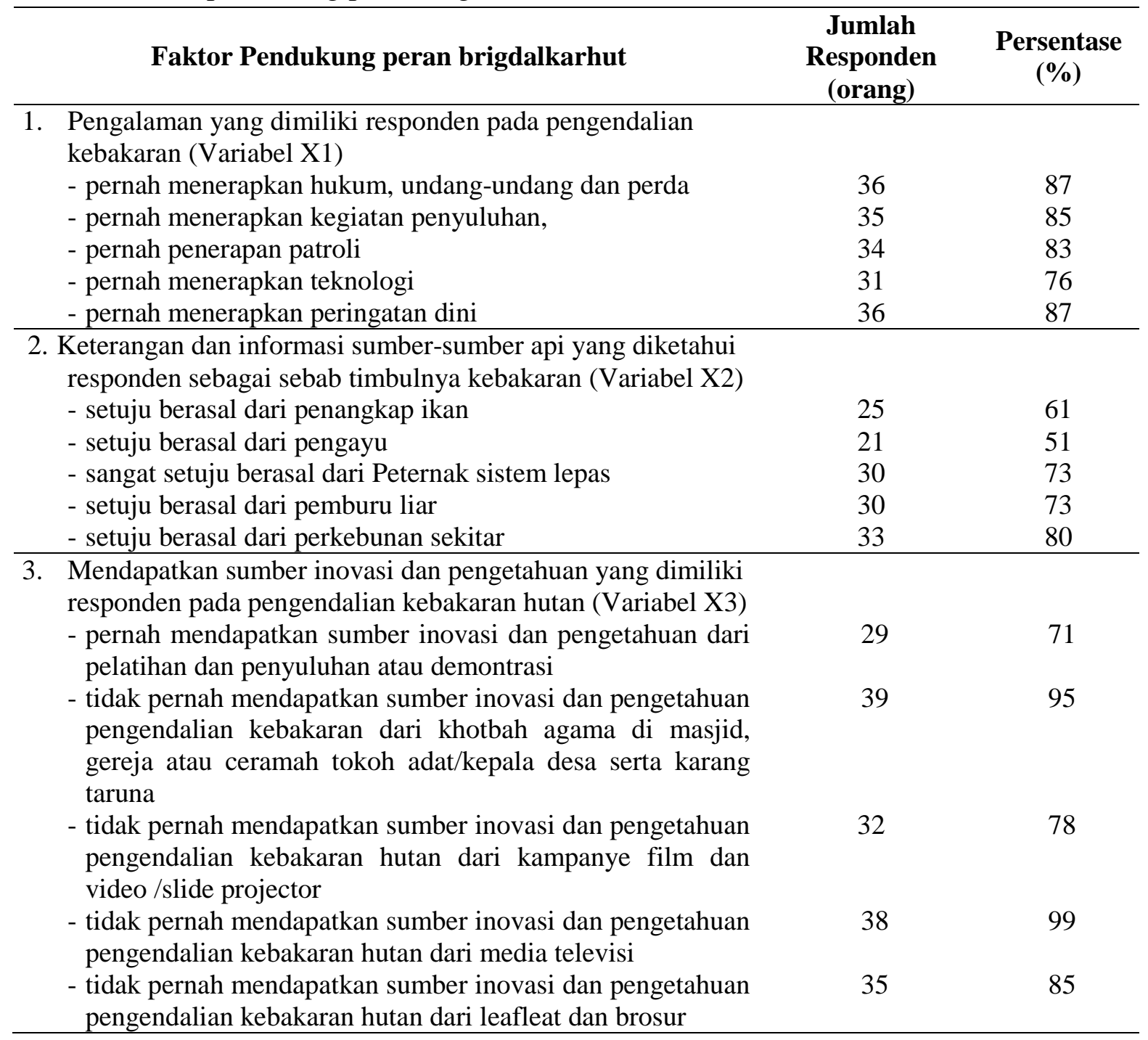


4. Program Kerja Dalam Menunjang Keberhasilan

Pengendalian Kebakaran (Variabel X4)

- tidak pernah mendapatkan pemahaman dalam menjalankan tugas berkala

- tidak pernah mendapatkan tambahan pengetahuan dan keterampilan berkala

- tidak pernah mendapatkan sarana dan fasilitas

- tidak pernah mendapatkan jadwal pengawasan lapangan berkala

- tidak pernah memberikan informasi laporan dini berkala

Sumber: Pengolahan data Primer

41
90

76

90

100

Pengalaman diartikan sebagai sesuatu yang pernah (dialami, dirasakan, ditanggung) (KBBI, 2017). Pengalaman dapat diartikan juga sebagai memori episodic yaitu memori yang menerima dan menyimpan peristiwa yang terjadi atau dialami individu pada waktu dan tempat tertentu, yang berfungsi sebagai referensi otobiografi (Daehler dan Bukato, 1985). Pernyataan responden merupakan hasil pengalaman yang mereka alami langsung semasa hidupnya di lingkungan mereka tinggal. Berdasarkan Tabel 1, diketahui bahwa pengalaman yang dimiliki responden terhadap pengendalian kebakaran hutan pernah menerapkan hukum, undang-undang, peraturan daerah, dan peringatan dini $87 \%$, lebih dari $76 \%$ pernah menerapkan penyuluhan, patroli dan teknologi. Kegiatan yang dilakukan meliputi penyadartahuan/kampanye pencegahan dan pengendalian kebakaran, peringatan sangsi apabila ada pelanggaran, teknik pemadaman kebakaran, penanganan pasca kebakaran, pembuatan sekat bakar dan kampanye pencegahan kebakaran hutan. Pelaksanaan patroli dilakukan responden berkolaborsi dengan anggota polisi hutan yang bertugas diwilayah kerja setempat, peringatan dini dilaksanakan dengan memasang papan larangan dan papan peringatan tentang pencegahan dan pengendalian kebakaran. Bambang dan Amalina (2016) mengungkapkan rendahnya informasi mengenai penyuluhan kepada masyarakat dan kurang diperhatikannya keberadaan papan peringatan adalah bentuk kurang optimalnya upaya pengendalian kebakaran.

Secara keselurahan tingkat pengalaman respoden persentase lebih dari $76 \%$, hal ini dimungkinkan mengingat pengalaman merupakan suatu proses pembelajaran dan pertambahan perkembangan tingkahlaku yang didapatkan baik dari pendidikan formal maupun non formal atau suatu proses yang membawa seseorang kepada suatu pola tingkahlaku yang lebih tinggi (Asih, 2006). Berdasarkan hasil penelitian, diketahui bahwa $73 \%$ responden mempunyai tingkat pendidikan kategori menengah yaitu SLTA. Hal ini menunjukkan bahwa responden cukup memiliki sumberdaya manusia yang bagus. Kategori pendidikan ini akan menjadi potensi yang bagus untuk mampu menyerap berbagai pengetahuan dan keterampilan serta berbagai teknologi dan inovasi yang diperkenalkan. Upaya membangun kualitas Sumber Daya Manusia (SDM) kehutanan tidak terlepas dari mutu pendidikan, seseorang yang berpendidikan lebih tinggi akan mempunyai pengetahuan yang lebih dibandingkan dengan seseorang yang pendidikan lebih rendah.

Keterangan dan Informasi sumber-sumber api yang diketahui responden sebagai sebab timbulnya kebakaran terdiri dari beberapa sumber. Sebanyak $73 \%$ responden setuju berasal dari peternak sistem lepas dan pemburu liar, $85 \%$ responden setuju berasal dari perkebunan disekitar, $51 \%$ responden setuju dari pengayu dan $61 \%$ responden setuju berasal dari penangkap ikan. Berdasarkan pengamatan lebih lanjut diketahui bahwa penangkap ikan mengeluarkan sumber api saat melakukan aktivitas perjalanan menuju rawa/tempat penangkapan ikan dan aktivitas pengolahan ikan ditempat, aktivitas pengayu pada kebiasaan merokok saat melakukan pengambilan kayu ditempat yang dituju. Pengayu dan penangkap ikan memiliki kebiasaan buruk membuang sembarangan dan membiarkan sisa api aktivitas 
mereka yang menjadi potensi timbulnya kebakaran. Peternak lepas adalah perorangan warga yang melakukan usaha peternakan, namun hewan ternaknya dilepaskan berkeliaran di sekitar kawasan hutan. Aktivitas peternak ini ketika melepaskan hewan piaraannya di kawasan hutan sering juga menimbulkan api yaitu pada aktivitas merokok yang dilakukannya. Perilaku merokok dan membuang sisa puntung rokoknya merupakan hal sama dengan yang dilakukan pengayu. Kecerobohan dan perilaku buruk yang mereka lakukan sangat beresiko menimbulkan dan menyebabkan sumber api. Sumber api yang dihasilkan dari pemburu liar memiliki potensi resiko yang sama. Pemburu liar biasanya lebih lama melakukan aktivitas di dalam kawasan hutan ketika berburu dapat lebih dari 3 hari di dalam kawasan hutan. Selain merokok, pemburu sering membuat api di dekat tenda peristirahatnya untuk kebutuhan konsumsinya, sehingga potensi datangnya sumber api juga lebih besar. Perkebunan yang ada sekitar kawasan TNWK adalah perkebunan rakyat dengan jenis tanaman karet, akasia dan jati sedangkan perkebunan swasta di kelola perusahaan PT Nusantara Tropical Farm (NTF) dengan jenis tanaman buah-buahan seperti pisang, jambu biji, dan durian. Berdasarkan pengamatan lapang aktivitas perkebunan yang dikelola secara intensif tidak terlihat adanya pengelolaan kebun dengan aktivitas mengeluarkan api kecuali pada pekerjanya. Aktivitas yang menimbulkan api dilakukan pekerja pada kegiatan merokok dan domestik. Rosmayani dan Pamungkas (2013), mengungkapkan bahwa salah satu faktor mempengaruhi kerentanan terhadap bencana kebakaran hutan dan lahan adalah kegiatan penduduk pada aktivitas penyiapan lahan untuk usaha pertanian dan kehutanan dan kegiatan penduduk membuang puntung rokok atau membakar api unggun ketika berkemah.

Sumber inovasi dan pengetahuan yang dimiliki $71 \%$ responden pada pengendalian kebakaran pernah diperoleh dari pelatihan, penyuluhan dan demontrasi dan $95 \%$ responden menyatakan tidak pernah memperoleh dari kotbah agama di masjid/gereja/tokoh adat/kepala desa/karang taruna, kampanye film dan $78 \%$ responden menyatakan tidak memperoleh dari video/slide projektor, $99 \%$ responden tidak memperoleh dari media televisi, serta $85 \%$ responden tidak memperoleh dari leafleat dan brosur. Berdasarkan hasil wawancara lebih lanjut diketahui bahwa pelatihan, penyuluhan dan demontrasi yang pernah diperoleh responden adalah pembuatan sekat bakar, penggunaan alat sederhana tanki dan pompa air. Rata-rata 10,75\% responden yang pernah memperolehan sumber inovasi dan pengetahuan pengendalian kebakaran dari pesan khotbah agama di masjid/gereja atau ceramah oleh tokoh adat/kepala desa/karang taruna, kampanye film dan video, slide projector, leafleat, brosur bahkan media telivisi. Dengan demikian diketahui bahwa masih sangat kurang ketersediaan sumber inovasi dan pengetahuan yang disampaikan kepada masyarakat khususnya anggota brigdalkarhut tentang pengendalian kebakaran hutan padahal media yang tersedia memiliki potensi penyebaran informasi. Hasil penelitian Siti dkk, (2016) diketahui bahwa faktor eksternal yang berhubungan terhadap partisipasi pencegahan kebakaran hutan terdiri dari peran penyuluh dan lingkungan sosial (dukungan tokoh masyarakat, peran kelompok, media informasi dan peran pemerintah).

Program penunjang keberhasilan pengendalian kebakaran diketahui bahwa semua responden sebanyak $(100 \%)$ tidak pernah mendapatkan tambahan pengetahuan keterampilan berkala dan tidak pernah memberikan informasi laporan peringatan dini. Sebanyak $90 \%$ responden tidak pernah mendapatkan pemahaman dalam menjalankan tugas dan tidak pernah mendapatkan jadwal pengawasan lapangan berkala. Sebanyak $76 \%$ responden tidak pernah mendapatkan sarana dan fasilitas.

Secara keseluruhan faktor pendukung peran brigdalkarhut dalam pengendalian kebakaran belum terlihat baik dan fasilitas dalam mengendalikan kebakaran juga masih kurang. Brigdalkarhut dan anggotanya belum memiliki program penunjang kerja demikian juga peran kelembagaan menjadi hal yang harus di evaluasi. Faktor yang menjadi hambatan dan tantangan dalam pengendalian kebakaran hutan yakni pembagian wewenang kawasan, 
keterbatasan alat, dimensi sumber daya alam dan sumberdaya manusia serta partisipasi masyarakat (Meiwanda, 2016).

\section{Peran Anggota Brigdalkarhut}

Peran adalah konsep perilaku yang dapat dilaksanakan individu sebagai bagian organisasi Soekanto (2002). Peran anggota brigdalkarhut hasil penelitian dicantumkan dalam Tabel 2 berikut :

Tabel 2. Peran Anggota Brigdalkarhut

\section{Peran Anggota Brigdalkarhut}

1. Peran Dalam Inisiatif Kegiatan Pengendalian

Kebakaran

- pernah hadir ketika ada rapat organisasi

organisasi

- keterlibatan dalam kegiatan kelompok sering timbul dari desakan atau paksaan lingkungan sekitar

- keterlibatan dalam kelompok sering secara suka rela timbul dari diri sendiri

- keterlibatan timbul atas perintah

2. Peran Dalam Pelaksanaa Pengendalian kebakaran

- sering memberitahukan orang yang dicurigai

Jumlah Responden (orang)

Persentase

- tidak pernah memberitahukan adanya sumber kebakaran area rawan api

- pernah memberitahukan ada kerusakan hutan

- pernah memberitahukan adanya tindakan membahayakan

- pernah memberitahukan adanya rencana membakar hutan

\section{6}

36

36

88

24

32

37

38

34 93

36
58 78 90 93 82
3. Peran Responden dalam Organisasi kerja dan

Pemeliharaan Pengendalian Kebakaran

- tidak pernah mendapatkan tambahan pengetahuan

dan keterampilan termutakhir tentang pengendalian kebakaran hutan

- tidak pernah merasakan senang dan puas menjadi

bagian anggota brigdalkarhut

- tidak pernah ada inovasi dan penambahan peralatan berteknologi mempermudah kerja pengendalian kebakaran hutan

- sering merasakan ada tambahan pengeluaran

- tidak pernah melakukan koordinasi dalam musim kemarau

4. Peran dalam Pencapain Tujuan Dan Penilaian Pengendalian Kebakaran

- tidak pernah mendapatkan pengetahuan terkini $\quad 37 \quad 90$

- sering keberatan adanya pengeluaran ekstra $\quad 39 \quad 95$

- perlu tambahan anggota $\quad 36 \quad 38$

- perlu tambahan peralatan berteknologi $\quad 39 \quad 95$

$\begin{array}{lll}\text { - ingin bergabung terus dalam brigdalkarhut } & 35 & 85\end{array}$ 
Berdasarkan hasil penelitian yang dicantumkan dalam Tabel 2 dapat diketahui bahwa peran responden dalam perencanaan kegiatan pengendalian kebakaran pernah hadir ketika ada rapat organisasi sebanyak 93\% dan aktif mengajukan pendapat sebanyak 59\%. Keterlibatan responden dalam kelompok sering timbul dari desakan atau paksaan lingkungan sekitar, secara suka rela/timbul dari diri sendiri dan atas dasar perintah sebanyak $88 \%$. Kegiatan rapat atau pertemuan anggota brigdalkarhut lebih banyak diadakan ketika menghadapi musim panas ekstrim/kemarau panjang. Pada saat rapat itulah responden mengajukan pendapatnya, namun berdasarkan informasi lebih lanjut masih terlihat sangat kurang inisiatifnya.

Keterlibatan responden dalam kelompok sering timbul dari desakan atau paksaan lingkungan. Hal ini diketahui ketika secara spontan responden langsung menangani pemadaman api ketika tiba-tiba bahaya kebakaran terjadi. Kondisi demikian memperlihatkan bahwa responden menyadari akan tugas dan fungsinya yang senantiasa siaga dan tanggap akan adanya bahaya dan kerugian kebakaran hutan. Seiring diketahui juga keterlibatan responden sering timbul atas perintah. Hal ini dimungkinkan terjadi mengingat pekerjaan utama responden lebih dari 85\% adalah Aparatur Sipil Negara di Balai TNWK sehingga mereka juga terikat perintah secara struktural. Sebagai bagian dari organisasi kerja Balai TNWK, kadang koordinasipun berdasarkan hubungan perintah misalnya saja adanya undangan rapat resmi atas perintah atasan dan lainnya. Secara umum data menunjukkan peran responden dalam kegiatan perencanan mempunyai persentase tinggi lebih dari $86 \%$. Hal ini membawa manfaat dalam memberikan masukan, konsep, saran serta mengungkapkan persoalan kebakaran hutan sehingga menjadi masukan dalam menjalankan program kerja organisasi. Menurut Mukau (2016), terdapat beberapa hambatan pengendalian kebakaran hutan dan lahan diantaranya hambatan yang berada ditahap perencanaan dan anggaran.

Peran serta pada pelaksanaan pengendalian kebakaran, sebanyak $58 \%$ responden sering memberitahukan orang yang dicurigai, sebanyak $78 \%$ responden tidak pernah memberitahukan adanya sumber kebakaran/area rawan api, pernah memberitahukan (adanya kerusakan hutan sebanyak 90\%, tindakan membahayakan sebanyak 93\% dan rencana membakar hutan sebanyak 82\%). Peran responden dalam pelaksaan pengendalian kebakaran masih dirasakan sangat kurang. Hal ini dimungkinkan karena responden cenderung tidak pernah mendapatkan sumber inovasi dan pengetahuan. Sumber inovasi dan pengetahuan yang dimiliki responden masih sangat kurang, oleh sebab itu diperlukan upaya perbaikan dalam tahap ini. Organisasi yang baik dan peran masyarakat dalam pengawasan hutan lebih maksimal merupakan motivasi untuk menjaga kelestarian hutan misalnya dengan melaporkan setiap gerak gerik pelaku perusak hutan untuk ditindak lanjuti (Sayendri, 2016). Upaya peningkatan peran serta responden dan masyarakat sekitar kawasan dengan pendekatan partisipatif akan mendorong partisipasi yang lebih besar sehingga mengembangkan kemandirian, mengurangi ketergantungan dengan metode Participatory Rural Appraial (PRA) (Hikmat, 2004).

Peran serta responden dalam organisasi kerja dan pemeliharaan pencegahan dan pengendalian kebakaran diuraikan sebagai berikut: sebanyak 95\% responden tidak pernah mendapatkan tambahan pengetahuan dan keterampilan, sebanyak $78 \%$ responden tidak pernah merasakan senang dan puas menjadi bagian anggota brigdalkarhut, sebanyak $95 \%$ responden tidak pernah mendapatkan tambahan peralatan berteknologi dan sebanyak $80 \%$ responden tidak pernah melakukan koordinasi dalam musim kemarau. Selain itu responden yang sering merasakan adanya tambahan pengeluaran sebanyak 90\%. Pengetahuan merupakan pondasi membangun keterampilan dan kemampuan kinerja organisasi sedangkan keterampilan adalah nyata menyiratkan tingkat kemahiran sehingga kemampuan menjalankan tugas sebagai anggota brigdalkarhut akan mudah terealisasi. Untuk itu sangat diperlukan penambahan pengetahuan dan keterampilan dalam satuan kerja brigdalkarkut terkait dengan pencegahan dan pengendalian kebakaran. Hasil penelitian Rahmad dan Sulaeman (2015) 
diketahui strategi pemberdayaan masyarakat dalam penanggulangan kebakaran hutan dan lahan diantaranya adalah meningkatkan keterampilan masyarakat dalam upaya penanggulangan kebakaran hutan dan lahan.

Kesuksesan kerja organisasi tidak hanya karena keahlian yang dimiliki anggotanya tetapi juga bagaimana membuat orang-orang dalam organisasi merasa senang dan setia pada pekerjaannya. Keinginan responden untuk terus bergabung pada brigdalkarhut perlu ditingkatkan mengingat pekerjaan dilapangan yang begitu berat dan resiko tinggi memungkinkan mereka meninggalkan keanggotan brigdalkarhut ini. Lingkungan kerja, disiplin kerja, motivasi untuk bekerjasama memiliki pengaruh positif dan signifikan terhadap kinerja (Sidati, 2015).

Peran dalam pencapaian tujuan dan penilaian pencegahan dan pengendalian kebakaran terdiri dari beberapa komponen yaitu responden tidak pernah mendapatkan pengetahuan terkini sebanyak 90\%, responden perlu tambahan anggota sebanyak $88 \%$ dan tambahan peralatan berteknologi sebanyak 95\%. responden ingin terus bergabung sebanyak $85 \%$ dan merasakan sering ada tambahan pengeluaran sebanyak 90\%. Pengetahuan dan keterampilan didapatkan hanya saat awal pelatihan anggota sementara formasi anggota mengalami perubahan pada anggota yang baru ada yang belum mendapatkan bekal pengetahuan dan keterampilan pengendalian kebakaran. Ketika berada dilapangan pengeluaran yang bersifat non teknis dan keperluan pribadi sering lebih banyak dikeluarkan misalnya penambahan biaya pemeliharaan peralatan dan akomodasi karena akses menuju lokasi begitu sulit.

Sebanyak $80 \%$ responden melakukan koordinasi dalam pengendalian kebakaran antar anggota/kelompok masyarat, sebanyak $88 \%$ responden berkorrdinasi dengan aparat desa setempat/stake holder, $100 \%$ responden berkoordinasi dengan petugas jaga dan $100 \%$ responden tidak pernah berkoordinasi dengan instansi lain/terkait. Dari hasil pengamatan lapangan koordinasi hanya dilakukan menjelang musim panas/kemarau dan koordinasi dengan instansi terkait hanya dilakukan oleh ketua koordinator pemadam kebakaran. Sementara anggota berkoordinasi terkait hal teknis dalam pelaksanaan pemadaman api. Fungsi kordinasi hanya berjalan ketika terjadi kegiatan pelaksanaan pemadaman api/bencana kebakaran berlangsung. Prinsipnya Koordinasi adalah proses yang kontinyu dan sepanjang waktu jika memungkinkan harus merupakan pertemuan bersama dalam anggota organisasi sehingga meningkatkan kinerja organisasi (Octrano, 2015). Lebih lanjut Shahira, (2015) mengungkapkan bahwa lemahnya koordinasi dalam menangani kebakaran hutan disebabkan beberapa faktor yaitu kurangnya pengawasan, kurangnya komunikasi, kurangnya kesadaran pentingnya koordinasi, kurangnya partisipan yang memiliki kompetensi, dukungan pendanaan dan fasilitas yang terbatas, kurangnya komitmen politik dan faktor hambatan lainnya.

\section{Analisis Kategori Peran Brigdalkarhut dalam Pengendalian Kebakaran Balai Taman Nasional Way Kambas}

Peran merupakan keterlibatan anggota brigdalkarhut secara aktif dalam melaksanakan kegiatan pengendalian kebakaran hutan di TNWK. Pelaksanan peran brigdalkarhut kategori sedang kecuali pada pelaksanaan kegiatan yaitu kategori tinggi. Kategori peran brigdalkarhut dapat dilihat pada Tabel 3 berikut:

Tabel 3. Kategori Peran responden

\begin{tabular}{lccccc}
\hline \multirow{2}{*}{ Kategori } & \multirow{2}{*}{ Range } & \multicolumn{5}{c}{ Peran brigdalkarhut } \\
\cline { 2 - 6 } & $1-5$ & $\mathbf{1}$ & $\mathbf{2}$ & $\mathbf{3}$ & $\mathbf{4}$ \\
\hline Rendah & $6-10$ & $27(66 \%)$ & $5(12, \%)$ & $7(17 \%)$ & $6(15 \%)$ \\
Sedang & $11-15$ & $8(19 \%)$ & $33(7 \%)$ & $32(78 \%)$ & $31(75 \%)$ \\
Tinggi & $\mathbf{4 1 ( 1 0 0 \% )}$ & $\mathbf{4 1 ( 1 0 0 \% )}$ & $\mathbf{4 1}(\mathbf{1 0 0 \%})$ & $\mathbf{4 1 ( 1 0 0 \% )}$ \\
\hline
\end{tabular}

Sumber: Pengolahan Data Primer 
Keterangan

$1=$ Peran dalamPerencanaan, 2 = Peran dalam pelaksanaan, $3=$ Peran dalam Organisasi kerja dan Pemeliharaan, 4 =Peran dalam Pencapai tujuan dan Penilaian Pengendalian Kebakaran hutan.

Berdasarkan Tabel 3 diketahui bahwa peran responden dalam kegiatan perencanaan berada pada kategori sedang sebanyak 66\%, yang berarti secara umum anggota Brigdalkarhut belum aktif terlibat pada tahap kegiatan perencanaan sehingga perlu upaya motivasi untuk meningkatkan keterlibatannya. Peran dalam pelaksanaan dapat dikatakan dalam kategori tinggi, Pada tahap pelaksanan seluruh anggota sudah berupaya melaksanakan tugas dan fungsinya mulai dari memberitahukan orang yang dicurigai, memberitahukan adanya kerusakan hutan, memberitahukan adanya tindakan yang membahayakan dan adanya tindakan rencana membakar hutan. Hasil Penelitian Sadono (2004), mengungkapkan peran serta semua stakeholder terutama masyarakat sekitar kawasan. dapat berjalan dengan baik apabila seluruh stakeholder dapat mengetahui informasi rencana kegiatan pengelolaan, menyatakan pendapat atau saran mengenai kebijakan pengelolaan, dilibatkan dalam pelaksanaan dan pengawasan kegiatan pengelolaan sehingga semua stakeholder mendapatkan manfaat dari kegiatan pengelolaan kawasan konservasi.

Peran serta dalam Organisasi kerja dan Pemeliharaan Pencegahan dan Pengendalian Kebakaran hutan dalam kategori sedang hal ini dikarenakan brigdalkarhut terlihat pada hasil penelitian program kerja dalam menunjang keberhasilan pengendalain kebakaran berada pada kategori tidak pernah ada program kerja dan kendala kurang sarana dan prasarana . Namun demikian responden harus dapat mengetahui tolak ukur apakah yang direncanakan telah sesuai dengan apa yang dihasilkan. Hasil penelitian Yuliani (2014) menyatakan bahwa setiap organisasi untuk dapat melaksanakan tugas dan fungsinya dengan baik, selain harus didukung oleh sumber daya manusia yang cukup dan berkualitas, dana yang cukup, juga harus dilengkapi dengan sarana dan prasarana yang memadai.

\section{Hasil Uji Statistik korelasi Rank Rs Spearman's Rho}

Pengujian secara parsial antara variabel X1 dan Y menunjukkan bahwa pengalaman responden pada sumber-sumber api yang dapat menimbulkan kebakaran berhubungan tidak nyata dengan peran brigade pengendalian kebakaran hutan dengan kooefisien korelasi Rank spearman $\left(r_{s}\right)$ adalah 0,159 dan tingkat signikikansi $0,320<\alpha / 2(0.05)$. Hal ini karena pengalaman responden belum dihimpun sebagai kekuatan untuk memperoleh data awal mengantisipasi terjadinya kebakaran, walaupun secara keseluruhan peran satuan kerja brigdalkarhut berada pada kategori sedang namun harus terus ditingkatkan berupaya menjadi lebih baik dalam menanggulangi kebakaran hutan

Hasil pengujian antara variabel $\mathrm{X} 2$ dan $\mathrm{Y}$ menunjukkan bahwa keterangan dan informasi sumber-sumber Api yang diketahui responden sebagai sebab timbulnya kebakaran berhubungan tidak nyata dengan peran brigade pengendalian kebakaran hutan dengan kooefisien korelasi Rank spearman $\left(r_{s}\right)$ adalah 0,138 dan tingkat signikikansi 0,390< $\alpha / 2$ (0.05). Hal ini karena keterangan informasi sumber api yang didapatkan belum ditindaklanjuti sebagai langkah awal informasi deteksi dini terjadinya kebakaran sebagaimana terlihat bahwa peran brigdalkarhut tahap perencanaan masih dalam kategori sedang.

Hasil pengujian antara variabel X3 dan Y menunjukkan bahwa Perolehan sumber inovasi dan pengetahuan yang dimiliki responden pada pengendalian kebakaran hutan berhubungan tidak nyata dengan peran brigade pengendalian kebakaran hutan dengan kooefisien korelasi Rank spearman $\left(r_{s}\right)$ adalah 0,385 dan tingkat signikikansi $0,013<\alpha / 2$ (0.05). Hal ini karena perolehan sumber inovasidan pengetahuan sebatas pada pelatihan, penyuluhan dan demontrasi tidak pernah mendapatkan informasi terkini dengan cepat melalui 
media elektronik ataupun teknologi yang mendukung sejalan dengan peran brigdalkarhut dalam organisasi kerja dan pemeliharaan berada pada kategori sedang.

Hasil pengujian antara variabel $\mathrm{X} 4$ dan $\mathrm{Y}$ menunjukkan bahwa bentuk program kerja menunjang keberhasilan penanggulangan kebakaran hutan berhubungan tidak nyata dengan peran brigade pengendalian kebakaran hutan dengan kooefisien korelasi Rank spearman $\left(\mathrm{r}_{\mathrm{s}}\right)$ adalah 0,181 dan tingkat signifikansi $0,257<\alpha / 2(0.05)$. Hal ini karena pelaksanaan program kerja belum berjalan dengan baik, belum ada penambahan pengetahuan dan keterampilan, sarana dan fasilitas kegiatan dilapangan masih kurang serta pemberian informasi dini dan pengawasan juga masih sangat kurang hal ini terlihat pula pada peran dalam pencapaian tujuan pencegahan dan pengendalian dalam kategori sedang.

Pengujian secara simultan antara variabel faktor pendukung peran satuan kerja brigdalkarhut $(\mathrm{X})$ berhubungan tidak nyata dengan peran brigade pengendalian kebakaran nutan (Y) yang ditunjukkan dengan kooefisien korelasi Rank Spearman $\left(r_{\mathrm{s}}\right)$ sebesar 0,244 dan tingkat signifikansi $0,159<\alpha / 2(0.05)$. Angka koefisien positif menunjukkan hubungan positif yaitu jika faktor pendukung peran brigdalkarhut meningkat maka peran brigdalkarhut juga meningkat. Kedua variabel terdapat hubungan yang linier pada hipotesis yang ada dalam penelitian ini dengan tingkat kepercayaan sebesar 95\% namun tidak nyata.

Hal ini sejalan dengan hasil penelitian Evayanti (2014) yang menyatakan bahwa faktor pendukung keterampilan/keahlian, organisasi, kesadaran, pendapatan, aturan dan sarana memberikan hubungan yang positif dan signifikan terhadap peran organisasi (Kasus masyarakat peduli api). Soekanto (2006) menyatakan peranan merupakan fungsi, penyesuaian diri, dan suatu proses dari suatu kedudukan. Hal ini berarti bahwa peranan akan mengatur perilaku seseorang. Peranan menentukan apa yang diperbuat seseorang bagi masyarakat serta kesempatan-kesempatan apa yang diberikan masyarakat kepadanya. Dari out put didapat signifikansi $<0,05$ maka ho ditolak jadi dapat disimpulkan bahwa ada hubungan antara faktor pendukung dengan peran anggota Brigdalkarhut.

\section{SIMPULAN}

Berdasarkan hasil penelitian dapat disimpulkan bahwa peran Brigdalkarhut pada pengendalian kebakaran hutan kategori sedang. Hubungan antara faktor pendukung peran brigdalkarhut dengan peran brigdalkarhut baik uji secara parsial maupun uji simultan keduanya menunjukkan hubungan yang tidak nyata.

\section{SARAN}

Untuk lebih meningkatkan peran Brigdalkarhut maka perlu ditingkatkan fungsi faktor pendukung, kompetensi anggota pada semua aspek dan keterlibatan semua stakeholder serta dipenuhi kelengkapan sarana dan prasara terutama pada kegiatan lapangan. 


\section{DAFTAR PUSTAKA}

Adinugroho WCI, Saharjo SBH dan Siboro L.2004. Panduan Pengendalian Kebakaran Hutan dan lahan Gambut. Wetlands Internasional - Indonesia Programme Canadian International Development Agency Agence canadienne de développement international Bogor.

Asih Dwi Annaning Tyas. 2006. Pengaruh Pengalaman Terhadap Peningkatan Keahlian Auditor Dalam Bidang Auditing. Fakultas Ekonomi. Universitas Islam Indonesia.

Bambang, H. S. dan Amalina, F. 2016. Potensi Kebakaran Hutan di KPH Bogor Perum Perhutani Unit III Jawa Barat dan Banten. Jurnal Silvi Kultur Tropika Vol 7 No:1 April 2016. 32-37.

Dwi P. 2009. 5 Jam Belajar Olah Data dengan SPSS 17. Yogyakarta.

Dwi Priyatno. 2008. Belajar Olah Data SPSS 17. ANDY Jogjakarta.

Daehler, Marvin dan bukatko, Danuta. 1985. Cognitive Development 1 Edition. New York: alfred A.Knopf.

Evayanti, T.2014. Partisipasi Organisasi Masyarakat Peduli Api (MPA) Terhadap Pencegahan Dan Pengendalian Kebakaran Hutan Dan Lahan Di Kabupaten Pelalawan Jurnal Ilmu Lingkungan. Jurnal Ilmu lingkungan (1) :8 2014.

Khulfi, M.K., Bahruni dan Syaufina. 2015. Nilai kerugian dan efektivitas Pencegahan Kebakaran Hutan Gambut (Studi Kasus di Taman Nasional Sebangau Propinsi Kalimantan Tengah. Risalah Kebijakan Pertanian dan Lingkungan. Vol 2 No:3 Desember 2015:214-229.

Kamus Besar Bahasa Indonesia (KBBI). kbbi.web.id.

Mukau.,T.S. 2016. Penerapan Sanksi Pidana Terhadap Pelaku Pembakaran Hutan atau Lahan Menurut Undang-Undang Nomor 32 tahun 2009. Lec Crimen Vol. V No: 4 April-Juni 13-21.

Meiwanda,.G. 2016. Kapasitas Pemerintah Daerah Provinsi Riau: Hambatan dan tantangan Pengendalian Kebakaran Hutan dan Lahan. Jurnal Imu Sosial dan Ilmu Politik. Volume 19, Nomor 3.251-263.

Permen LHK RI No:P.32/Menlhk/Setjen/Kum.1/3/2016 tentang Pengendalian kebakaran hutan.

Octorano,.D.F. 2015. Pengaruh Koordinasi, Kompetensi dan Disiplin terhadap Kinerja Pegawai Unit Layanan Pengadaan Kementrian Agama Pusat (ULP Kemenag Ousat). Jurnal MIX, Volume V,No.1, 108-123.

Rahmat Danil, Defri Yoza dan Rudiana Suleman. 2015. Strategi Pemberdayaan Masyarakat dalam Penanggulangan Kebakaran Hutan dan Lahan di Kabupaten Rokan Hilir. JOM. Bidang Pertanian Vol2 No:1.1-12.

Rasyid F. 2014. Permasalahan dan Dampak Kebakaran Hutan.www.Juliwi.com Edisi 1 No 4 Oktober-Desember. P.47-59. 
Rosmayani,.N.L dan Pamungkas, A. 2013. Identifikasi Faktor-faktor kerentanan terhadap bencana Kebakaran hutan dan Lahan di Kecamatan Liang Anggang Kota Banjar Baru. Jurnal Teknik POMITS Vol.2, No.2 C207-C210.

Sayendri,.D. 2016. Partisipasi Masyarakat Peduli Api dalam Penanggulangan Kebakaran Hutan dan Lahan (Study Kasus di Kecamatan Bunut Kabupaten Pelalawan Tahun 20102013) Jom FISIP Vol.3 No.3.

Sidati, H.,2015.Pengaruh Lingkungan Kerja, Disiplin Kerja dan Motivasi Kerja Terhadap Kinerja Pegawai Negeri Sipil di Sekretariat DPRD Kabupaten Madiun. Jurnal JIBEKA Volume 9 Nomor: 1 .44-53.

Suheri dan Eko Priyo Purnomo. 2017. Penguatan Kelembagaan dalam pencegahan dan Pengendalian Kebakaran Hutan dan Lahan Di Kabupaten Muara Jambi Propinsi Jambi. Jurnal of Governance and Public Policy. Vol 4 No:1 .175-203.

Sunanto.2008.Tesis. Peran Serta Masyarakat Dalam Pencegahan dan Penanggulangan Kebakaran Lahan (Studi Kasus Kelompok Peduli Api Di Kecamatan Rasau Jaya Kabupaten Kubu Raya Provinsi Kalimantan Barat) Program Magister Ilmu Lingkungan Program Pasca Sarjana Universitas Diponegoro Semarang.

Shahira,. H dan Yusri,.A.2016.Koordinasi antara pemerintah Propinsi Riau dan Pemerintah Kabupaten Rokan Hilir Dalam Menangani Kebakaran Hutan dan Lahan Karhutla di Rokan Hilir Tahun 2010-2013. JOMFISIP. Februari 2016. Vol 3. NO:1 1-13

Singarimbun.M dan Effendi, Sofian. 1989. Metode Penelitian Survai. LP3ES, Jakarta

Sugiyono. 2009. Metode Penelitian Kuantitatif Kualitatif dan R\&D. alfabeta. Bandung.

Siegel.,S .1999. Statistika Non Parametrik Untuk Ilmu Ilmu Sosial. Gramedia. Jakarta.

Soekanto,S. 2012. Sosiologi Suatu Pengantar. RajaWali Pers. Jakarta.

Sadono. 2013. Peran Serta Masyarakat dalam Pengelolaan Taman Nasional Gunung Merbabu di Desa Jeruk Kecamatan Selo, Kabupaten Boyolali. Jurnal Pembangunan Wilayah Kota Volume 9 (1): 53-64.

Siti Sawerah, Muljono dan Tjiptoprano. 2016. Partisipasi Masyarakat dalam Pencegahan Kebakaran Lahan Gambutdi Kabupaten Mempawah Propinsi Kalimantan Barat. Jurnal Penyuluhan Maret 2016.Vol 12 No:1

Yuliani F. 2014. Partisipasi Masyarakat Dalam Implementasi Kebijakan Pengendalian Kebakaran Hutan DanLahan Di Kabupaten Rokan Hilir. F. Fakultas FISIP UNSRI. Repository .Http://repository.unsri.ac.id/

Yitnosumarno, S. 1994. Dasar-Dasar Statistika Dengan Penekanan Terapan Dalam Agrokompleks. Teknologi dan Sosial. Buku. Raja Grafindo Persada. Jakarta. 